\title{
The Policy Brief Assignment: Transferable Skills in Action in a Community-Engaged Writing Project
}

\author{
Laurie Grobman, Penn State University, Berks
}

January 1, 2017

\begin{abstract}
The policy brief assignment in my capstone course in professional writing was designed as a community-engaged project in partnership with a nonprofit organization whose mission is to grow Reading, Pennsylvania's economy. The assignment was intended to do real work in the world: the nonprofit's director, a city council member, and an outreach manager for the city of Reading plan to use the policy briefs to convince Reading's City Council to adopt the recommended policies to enhance citizen participation and representation in local governance and to address deficiencies identified through the STAR Community Rating System(r) (STAR), the nation's leading sustainability framework and certification program (STAR 2016). I welcomed the collaboration and designed the assignment with the goal that students would experience what writing faculty always tell them: fundamental concepts in composition and rhetoric/writing studies are operational in the workplace, and understanding writing and communication rhetorically opens up possibilities for them to enter diverse and unfamiliar writing contexts. Students successfully researched, synthesized, organized, and clearly communicated information in a content area and genre new to them. They presented their policy briefs in written and electronic form to the community partners and explained their work in oral presentations. It was an exciting, nerve-wracking, and challenging endeavor, and, as I will describe, the periods of dissonance led to the best learning experiences-for students and for me.
\end{abstract}

The term community-engaged project is used in the discipline of Rhetoric and Composition to refer to "scholarly, teaching, or community-development activities that involve collaborations between one or more academic institutions and one or more local, regional, national, or international community group(s) and contribute to the public good 
(Conference on College on Composition and Communication, 2016). It is part of the national movement called for in The Engaged Institution: Returning to Our Roots (1999), the Kellogg Commission's plea for institutions of higher education to (re)commit their resources to the communities they serve.

The partnership was initiated by the director of an economic development nonprofit organization in Reading (pseudonym Bradley); Bradley linked us with a Reading City Council member (pseudonym Robert) and an outreach manager for the city's Public Works department (pseudonym Jennifer) because both had an interest in the policy brief topics Bradley selected for the students to study. I had met Bradley while working on another community-engaged scholarship project (I am the Coordinator of the college's Center for Service Learning and Community-Based Research), and he asked whether I thought students at the College would be interested in conducting research on the STAR Community Rating System(r) (STAR), the nation's leading sustainability framework and certification program (Communities, 2016). STAR provides a clear, data-driven approach to assessing communities' sustainability efforts and to tracking and guiding their efforts. Reading became the first municipality in the state of Pennsylvania to achieve STAR certification with a score of 234.1, which qualifies the city as a 3-STAR Community in sustainability; higher ratings of 4-star and 5-star are also offered within the program. Bradley, through an agreement with the Mayor's office, did most of the work for STAR certification, and he plainly stated that he needed assistance as they began to address some of the gaps and to prepare for the next certification round.

The policy briefs were solicited by the community partners to address two specific gaps in Reading's policies and initiatives, identified by the STAR process:

- A policy to encourage diversity in local government appointments to advisory boards and commissions

- A set of guidelines to instruct local government agencies or departments about how to successfully engage residents

I welcomed the collaboration and designed the assignment with the goal that students would experience what writing faculty always tell them: fundamental concepts in composition and rhetoric/writing studies are operational in the workplace, and understanding writing and communication rhetorically opens up possibilities for them to enter diverse and unfamiliar writing contexts. Students successfully researched, synthesized, organized, and clearly communicated information in a content area new to them. They also wrote in a new genre-policy briefs-as they learned this new genre. They saw in practice what Charles Bazerman describes as genres as "environments for learning. They are locations within which meaning is constructed" (1997, p. 19). They collaborated using several technologies with their peers, professor, and community professionals. They prepared their presentations for an audience with varying levels of expertise and familiarity with city government, Reading, and STAR, from faculty in the English major to the dean at the college to the community partners. It was an exciting, nerve-wracking, and challenging 
endeavor, and, as I will describe, these periods of dissonance led to the best learning experiences-for students and for me.

\section{Assignment Description}

The culminating course in the Professional Writing major, English 491: The Capstone Course in Professional Writing, serves as a stepping stone between the academic study of professional writing and the real-world application of the skills, abilities, and knowledge students acquired through the coursework and curriculum. Part of the course focused on the current professional landscape for writers (Blythe et al., 2014; Brumberger \& Lauer, 2015; Hart Research Associates on Behalf of the Association of American, 2015), contextualized within the value of a liberal arts degree (American Academy's Commission on the Humanities and Social Sciences, 2013; Humphreys \& Kelly, 2014), in terms of potential employment and graduate school. ${ }^{1}$ Together, these readings drove home the point that the knowledge and skills students learn in the professional writing major and the liberal arts more generally prepare them for numerous professional opportunities. As reported in Falling Short: College Learning and Career Success:

[E]mployers say that when hiring, they place the greatest value on demonstrated proficiency in skills and knowledge that cut across all majors. The learning outcomes they rate as most important include written and oral communication skills, teamwork skills, ethical decision-making, critical thinking, and the ability to apply knowledge in real-world settings. Indeed, most employers say that these cross-cutting skills are more important to an individual's success at their company than his or her undergraduate major. (Hart Research Associates on Behalf of the Association of American, 2015, p. 1)

Unfortunately, "employers feel that today's college graduates are not particularly well prepared to achieve the learning outcomes that they view as important (Hart Research Associates on Behalf of the Association of American, 2015, p. 1). The policy brief assignment intended to put students in a real-world professional situation to illustrate to them that they are critical thinkers with transferable, cross-cutting skills.

The public policy assignment brought together research skills in an unfamiliar content area, critical thinking skills to understand and communicate about this new content area, rhetorical and writing skills to quickly learn a new genre, team work and collaboration, oral presentation skills, and writing for a public purpose. It required that all of usstudents, community partners, and me-learn on the fly as students researched and wrote material that was intended to have substantive consequences for resident participation in local governance.

Across the nation and in at least two other campuses of Penn State University (PSU), I learned, students are engaging with city administrations and organizations to assist with STAR certification. The policy brief assignment can be replicated, and I have already shared the assignment with colleagues at the other PSU campuses. Further, 
the policy brief assignment is one of literally hundreds of possible research, writing, and critical analysis opportunities presented by the 365-page STAR Technical Guide and certification process. I had the benefit of a small, senior-level class and could have handled up to 20 students. I also believe the STAR Rating System offers a multitude of learning opportunities for students across disciplines and course levels.

\section{Dissonances and Learning}

Many facets of the process and partnership led to challenges which, ultimately, provided productive learning experiences. In service learning literature, challenges are sometimes referred to as "dissonances," defined by Doerr as "the transformative experience students involved in service learning gain through confronting the complexity of the issue at hand" (2011, p. 71). ${ }^{2}$ For example, the STAR Technical Guide is 365 pages with a framework including more than 500 data points broken down by goals, objectives, outcomes, and local actions. The students also had to distinguish between guidelines, principles, and initiatives, terms used in sometimes confusing ways in the Guide. The students were tasked by Bradley with providing policy briefs for Local Action 1, "Adopt a policy to encourage diversity in local government appointments to advisory boards and commissions," and Local Action 2, "Adopt guidelines to instruct local government agencies or departments about how to successfully engage residents," of Goal 5 (Equity and Empowerment), Objective 1 (Civic Engagement). I required that students read the Guide's Introduction and "Equity and Empowerment" chapter. We spent a full class period discussing the language and structure of the Guide, and Bradley and Robert attended another full class period to explain the Guide and overall certification process. Still, given the relatively short time frame (something I would do differently next time by adding one additional week to the project), understanding the Technical Guide was a daunting task.

In addition, students had to figure out where and how to find information about effective policies on civic engagement and diversity of representation on Boards and Commissions. The research was new for most students: instead of library databases, they found answers through online searches yielding documents such as city ordinances, community development reports, City Charters, and meeting minutes. Bradley instructed the students to look at policies and procedures in other cities and to conduct comparative analyses as part of their research methods. But first, students needed to understand local contexts-if Reading's government is different from Portland's, for example, does the comparison make sense?

Students did make their way through the morass of new information and information sources. It was their idea to go look through the policies of all STAR cities with 5-STAR ratings as a starting point. It was their decision to compare and contrast Reading's applications for Boards and Commissions to other cities', and from there they noticed that Reading's application included many questions that were exclusionary of low-income residents. The students' third recommendation in the policy brief was: 
Replace Reading's application for boards/committees with an application similar to Portland's (attached to this brief) to eliminate questions about owning property or businesses in the city or any water/sewer bills, property taxes, codes violations, or fines which are delinquent for six months or longer. These questions may deter or eliminate from Boards and Commissions a significant portion of individuals, given Reading's high poverty rate, $39.6 \%$ in 2013. Portland's application also includes an optional section on age, race/ethnicity, gender, and disability to help "ensure that appointments represent a broad cross-section of the community."

The partners strongly agreed with this recommendation; Councilperson Robert, an African American man who grew up in Reading, forthrightly offered his perspective on the transitional demographics and power shift that will and must take place if Reading is to become an economically sustainable community.

Doerr also refers to the dissonance service-learning educators experience from "a sense of personal conflict" (2011, p. 71). Although this dissonance is sometimes discouraging, it generates "tough and critical questions about the effectiveness of service-learning" (Doerr, 2011, pp. 71-72). Although I have sixteen years of experience with service learning and community-based research, I was new to policy briefs, local city government, and STAR certification. In other words, I had a great deal to learn about content, research sources, and I assumed-without question-that I, their professor, would easily accomplish these tasks while also showing them that they had the skills and knowledge to do so as well. Further, working with undergraduate students in a community-engaged project was new territory to two of the partners. Thus, we were all tested when feedback from one of the community partners on the students' first submitted drafts arrived straight to their email inboxes.

The feedback was harsher than students were accustomed to; writing faculty spend a great deal of time on using careful language to critique and provide revision suggestions while also pointing out strengths in the writing. However, our "real-world" partner was not a teacher and was not thinking like a teacher; rather, he was thinking as a professional person with too much on his plate and too little time to get it done. The feedback from Bradley went directly to the students via email because as part of the assignment, I required them to submit their draft to in a professionally written email by the group. I wanted them to have this "real-world" experience, but had not anticipated the negativity of the feedback. I was embarrassed by what felt to me like my failure and that my failure caused the students to lose confidence in their transferrable skills. I had closely guided the students on the work and thought the drafts would do the work in the world they were intended to do: influence policy on civic engagement.

Moreover, the students and I felt strongly that a significant component of feedback contradicted explicit instructions from our partners. Bradley stated, "what is the current language in City of Reading code/charter that discusses community involvement? Did you talk to any Reading civil servants? At a minimum, that creates a baseline that you did your research, otherwise, many elected officials might discard the entire thing." In 
the Q\&A portion of the presentation, I specially asked Bradley whether the students needed to conduct research to justify the "problem" in each brief-the lack diversity in local government appointments to advisory boards and commissions and the lack of effective engagement of residents in city governance, respectively. Bradley replied that simply by stating that the city received zero credit in the STAR certification process for these categories was sufficient evidence of the problem. It was difficult for me to negotiate students' hurt feelings and lack of trust in our community partners moving forward, especially because we were up against the semester's end. Yet I knew that even though the recording of the class presentation (with our partners' permission) validated the direction the students took in their briefs, my job was to guide the students to revise the briefs to meet the partners' needs. This involved reminding students that we were all learning "on the job"-our partners included-and that their process was probably much like ours in that we all understood better what was needed once we began learning the information. I facilitated a deal with students and the partners: that students would do the additional new research to complete the truncated briefs, but because the time left in the semester was short, they would have to forgo providing a full research report to accompany the briefs.

Together, students and I embarked on this new research; I worked more closely with students in these final weeks than I have ever done before in my classes. I became a student along with them as we dug into documents such as the Home Rule Charter of the City of Reading and the Code of Ordinances. Students felt like novices summarizing, paraphrasing and citing from these documents, but they ultimately conveyed the information succinctly and clearly, as in the following student-written paragraph:

Reading's governing documents provide for public participation but in limited ways. Article II, Section 213 of the "Home Rule Charter of the City of Reading" states that citizens have the right to be heard; Article X, Section 1001, encourages participation of citizens through boards and commissions; and Article XI, Section 1101, states that citizens have a right to participate in City Council. In addition, Ordinance No. 22-2013 established a Citizens Advisory Board, with the stated purpose of "act(ing) as a communication vehicle between city government and city residents on city-wide policies."

Students also located a Strategic Plan for the city but were informed that it was in draft form and under consideration by City Council; the students had to navigate their research on Reading in a time of transition with a new Mayor and new members of City Council. It was an especially divisive time in city government due to charges of corruption in the former Mayor's office and guilty pleas on bribery and related charges from two prior city officials.

Another experience of productive dissonance arose when our community partners explicitly informed the students that power holders often purposefully hinder citizen participation by being non-transparent, for example by following policies about announcing public meetings at the very last minute. Students were disappointed to find evidence of these 
deliberate exclusionary politics through their research. One student recommendation, that "Reading needs specific guidelines in place that more extensively and effectively encourage participation from citizens, such as an 'internal document that is consulted when involving the public in decision making processes,'" emerged as the result of students' research and analyses that illustrated what happens when diverse citizens have-and do not have-a voice in government. Thus, the policy brief assignment worked as community-engaged scholarship on two levels: students were simultaneously enacting democratic participation and social justice work and learning in profound ways about exclusionary and inclusionary politics, power, race, socioeconomic status.

These challenges, or dissonances, were ultimately productive, if assessed by the community partners' satisfaction with the policy briefs; we were told they exceeded expectations and will be presented to City Council. As such, the students' work may positively influence public policy in Reading. The city administrator in the project told the students their briefs, presentations, and responses to her questions illuminated much about pursuing civic engagement initiatives in the city, regardless of Council's action.

The community partners and I are planning to begin conversations about working together next spring when I teach the capstone class again. I am eager to repeat the policy brief assignment, confident that productive dissonances will emerge in different ways in this administration's second year, having been informed that this administration is continuing the STAR Certification process, but the partnership with the nonprofit organization is through a different department. I am also willing to create an assignment around the community partners' needs, given these changing circumstances and that the STAR process will be a year further along and may require different kinds of research assistance. Clearly, I am drawn to the "exhilarating chaos"-the risks and rewards-of community-engaged pedagogical partnerships (Cella, 2013, p. 2).

\section{Assignment-Researching, Writing, and Presenting a Policy Brief: Transferable Skills in Action in a Community-Engaged Writing Project}

See the Supplementary Files for this article at thepromptjournal.com for a PDF facsimile of the original formatting of this assignment.

You will work with a small group of classmates to write a comprehensive policy brief in partnership with a nonprofit organization that partners with the city of Reading's administration; its housing, redevelopment and parking authorities; and the Downtown Improvement District to find nontraditional ways to grow the city's economy. Our main partners are a staff member from the nonprofit, a city councilman, and an outreach manager for the city of Reading.

There are many resources on policy briefs; I find the Food and Agricultural Organization of the United Nations description and resource guide to be useful, and in particular, its definition of a policy brief: 
A policy brief is a concise summary of a particular issue, the policy options to deal with it, and some recommendations on the best option. It is aimed at government policymakers and others who are interested in formulating or influencing policy. (http://www.fao.org/docrep/014/i2195e/i2195e03.pdf)

The assignment is designed so that your policy brief does real work: our community partners plan to use your policy briefs to convince Reading's City Council to adopt your recommended policies to enhance citizen participation and representation in local governance.

\section{Background}

The policy briefs are integrally related to Reading's participation in The STAR Community Rating System(r) (STAR), the nation's leading sustainability framework and certification program (http://www.starcommunities.org/rating-system/framework/). Reading became the first municipality in the state of Pennsylvania to achieve STAR certification with a score of 234.1, which qualifies the city as a 3-STAR Community in sustainability. STAR provides a clear, data-driven approach to assessing communities' sustainability efforts and to track and guide their efforts.

Sustainability is also a major strategic aim of Penn State University. Sustainability, as defined by PSU, is "the simultaneous pursuit of human health and happiness, environmental quality, and economic well-being for current and future generations" (http://sustainability.psu.edu/fieldguide/what-is-sustainability/).

\section{How Does STAR Work? This information comes from the STAR Technical} Guide.

\section{STAR includes seven Sustainability Goals:}

1. Built Environment: Quality, Choice \& Access Where We Live, Work, \& Play

2. Climate \& Energy: Increase Efficiency, Reduce Impact

3. Economy and Jobs: Quality Jobs, Shared Prosperity

4. Education, Arts \& Community: Vibrant, Connected \& Diverse Culture

5. Equity \& Empowerment: Inclusion \& Access for All Community Members

6. Health and Safety: Strong, Resilient, \& Safe

7. Natural Systems: Protect \& Restore the Resources of Life

Within each of the above Sustainability Goals, there are between 5-7 Objectives. These 44 objectives are the core areas that contain evaluation measures and metrics. 
Each of the Objectives above contains two types of evaluation measures: Community Level Outcomes and Local Actions.

Community Level Outcomes are measurable, condition-level indicators that show community progress on a STAR Community Rating System Objective.

Local Actions are the things you do to move toward the Community Level Outcomes - the range of decisions, investments, programs, plans, and codes that a local community puts in place.

\section{Your Work in this Class}

The city of Reading performed poorly in the Goal, "Equity and Empowerment" (EE) and received zero credit for Objective 1, Civic Engagement. Your policy briefs are intended to guide the city to take important actions in this area to enhance citizen participation and representation in local governance.

Group A

Goal: Equity and Empowerment (EE)

Objective 1 (Civic Engagement)

Local Action 1: "Adopt a policy to encourage diversity in local government appointments to advisory boards and commissions."

Group B

Goal: Equity and Empowerment (EE)

Objective 1: Civic Engagement

Local Action 2: "Adopt guidelines to instruct local government agencies or departments about how to successfully engage residents."

This information will become clearer when you read the relevant parts of the Technical Guide and listen to and converse with our partners.

\section{Learning Objectives}

Research, synthesize, organize, and present information in a content area new to most of you.

Write in a new genre as you learn a new genre ("on the fly").

Collaborate with your peers, professor, and community partners.

\section{Graded Components}

1. Policy Brief $\left(1^{\text {st }}\right.$ draft will be reviewed by a community partner, and you will revise it based on his feedback) (15 points)

2. Oral presentation to community partners (10 points) 
3. Full Research Document - This document includes and organizes the substantial amount of research your group undertakes and collects before writing the policy brief. Our partners will refer to this source for information not on the policy brief itself. (10 points)

\section{Timeline}

The outline below is a general guideline. You will need to pay close attention to my post-class period email summaries of what you are expected to complete for homework. Remember, we are all learning as we progress through the project.

- Week 1: Policy Briefs

- Week 2: Research

- Week 3: Draft Policy Brief

- Week 4: Presentation

\section{Notes}

\footnotetext{
${ }^{1}$ Of the six students in the class, three were preparing for graduate school and three were planning to go on the job market.

2 "Dissonance" is also often used to describe the transformational learning students undergo through border crossing: "High-intensity dissonance such as witnessing extreme forms of poverty, hunger, scarcity, and disease . . . often causes powerful emotions and confusion and leads study participants to reexamine their existing knowledge and assumptions regarding the causes and solutions to ambiguous and ill-structured problems" (Kiely, 2005, p. 11).
}

\section{References}

American Academy's Commission on the Humanities and Social Sciences. (2013). The Heart of the Matter: The Humanities and Social Sciences for a Vibrant, Competitive, and Secure Nation. Cambridge, MA.

Bazerman, C. (1997). The life of genre, the life in the classroom. In W. Bishop \& H. Ostrom (Eds.), Genre and writing: Issues, arguments, alternatives (pp. 19-26). Boynton/Cook.

Blythe, S., Lauer, C., \& Curran, P. G. (2014). Professional and Technical Communication in a Web 2.0 World. Technical Communication Quarterly, 23(4), 265-287. http://doi.org/ $10.1080 / 10572252.2014 .941766$ 
Brumberger, E., \& Lauer, C. (2015). The Evolution of Technical Communication: An Analysis of Industry Job Postings. Technical Communication, 62(4), 224-243.

Cella, L. J. (2013). Introduction: Taking Stock of Our Past and Assessing the Future of Community Writing Work. In Restaino \& L. J. Cella (Eds.), Unsustainable: Re-imagining Community Literacy, Public Writing, Service-Learning, and the University (pp. 1-14). Lanham, MD: Lexington Books.

Communities, S. (2016). STAR Communities. http://www.starcommunities.org/.

Conference on College on Composition and Communication. (2016). CCCC Statement on Community-Engaged Projects in Rhetoric and Composition. http://www.ncte.org/ cccc/resources/positions/community-engaged.

Doerr, E. (2011). Cognitive dissonance in international service-learning. In B. Porfilio \& H. Hickman (Eds.), Critical service-learning as revolutionary pedagogy: A project of student agency in action (pp. 71-94). Charlotte, NC: Information Age Publishing.

Hart Research Associates on Behalf of the Association of American. (2015). Falling Short? College Learning and Career Success. Association of American Colleges $\&$ Universities. Text, https://www.aacu.org/leap/public-opinion-research/2015-survey-results.

Humphreys, D., \& Kelly, P. (2014). How liberal arts and sciences majors fare in employment: A report on earnings and long-term career paths. Washington, DC: Association of American Colleges and Universities.

Kellogg Commission on the Future of State and Land-Grant Universities. (1999). Returning to our roots: The engaged institution (Vol. 3). Washington, DC: National Association of State Universities and Land-Grant Colleges, Office of Public Affairs.

Kiely, R. (2005). A transformative learning model for service-learning: A longitudinal case study. Michigan Journal of Community Service Learning, 12(1), 5-22. 